\title{
痴呆患者の笑い表情の収録と解析
}

\author{
○河合 隆史*，松岡 成明落，野呂影勇 \\ (*:早稲田大学, *:産業医科大学)
}

\section{A Fundamental Study on Laughter Expressions of Patients with Dementia}

Takashi KAWAI, Shigeaki MATSUOKA and Kageyu NORO

(*: Waseda Univ., **: Univ. of Occupational and Environmental Health)

\section{1. はじめに}

表情は，脳の活動が反映されたものであり， 感情の種類によって支配する部位が異なると考 えられている.また，非言語コミュニケーショ ンにおいても, 表情は最も重要なチャンネルで あり，個人の内的感情を推測する手がかりとな る. 数ある表情の中でも, 幸福の感情の表出で ある笑い表情が，最も判断が容易であるとされ ている。そこで本研究では，痴呆患者の表情と して笑いに着目し，笑い表情の収録と解析を 行った.

\section{2. 目的}

本研究においては，笑いの表情の指標とし て, 次の 2 種類に分類した. 1 つは, 眼元の笑 いである.もう1つは，口元の笑いである. 眼 元の笑いは，主として眼輸筋によって形成さ れ，前頭連合野（新皮質）が関係しているとい う. 一方, 口元の笑いは主として口輪筋によっ て形成され，辺縁系が関係しているという。し たがって,眼元の笑いは人間でなければできな い笑いといえるのに対して, ロ元の笑いは原始 的であると考穴られる。

以上の見解を前提として, 痴呆患者の笑い表 情の収録を行い，その所見から痴呆の表情に与 える影響を検討することが本研究の目的であ る. 将来的には, 非侵襲的な痴呆の診断などの パラメディカルな応用が期待できる.

\section{3. 方法}

実験は, 主として下関市の昭和病院にて行っ
た. 実験室には，解放感を高めるため, リハビ リテーションルームを選定し, その一角に, 収 録システムを設置した (図1)。収録には, ハー フミラーを用いた臨場感通信システムを使用し た. 呈示内容には, ホームビデオで撮影した子 供や動物のハプニングや失敗などを, 20 分程度 に編集したものを使用した。

また，予備実験において，検者との会話に よって患者の笑い表情が多く誘発されたことか ら, 測定システムに, お互いの顔を見て, 自由 にコミュニケーションができる機能を付加し た.このような対話型の測定システムは, ビデ オを観察しても笑い表情を形成しない被験者に 対して，とりわけ有効であった.

ビデオと対話という2 種類の条件で，のべ 21 例の被験者 (58〜89歳)の表情を測定した. な お，痴呆患者と非痴呆患者は， CTや長谷川式久 コア，および神経学的所見などの, 臨床データ から判別した.

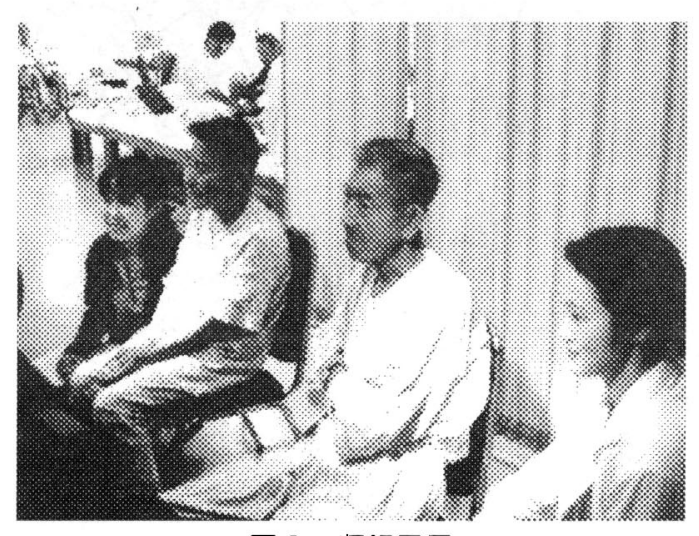

図 1 収録風景 


\section{4. 結果}

表情の数值化を行う際のパラメータとして, 眉・眼・口の上下左右端に特徴点を設定するこ とが一般的である。笑い表情では，眼裂の上下 の収樎, 左右の口角の伸長という, 一貫した距 離変化が見られる。 そこで, 左右の眼裂の動き と口角の動きを，特徵点間の距離として求め た．具体的には，笑い始めから笑い形成までの 被験者の表情を,等間隔で6フレーム抽出し, コ ンピュータ上での座標系から距離データ(単 位：ピクセル）として計測した。さらに, 測定 時の画角の差や個人差を等質化するために, 各 被験者の笑い始めの特徵点間距離をべースライ ンとした変化率に変換した。

痴呆患者と非疾呆患者の間では, 左右眼の特 徵点間の距離変化が, 非痴呆患者において顕著 に大きかった.しかしながら，口角に関しては， 差は認められなかった. 各特徴点間距離の時系 列的な変化の結果を, 図 2〜3に示す. 非疾呆 患者では, 笑い始めに両眼での左右差が見られ たが，笑い表情形成までの後半では, 左右差は 認められなかった，全体的には，概ね線形の距 離変化といえる。一方, 痴呆患者の結果では, 両眼での左右差が顕著であり, 時系列的な変化 も非線形であった。

\section{5. おわりに}

本実験の結果から, 次の 2 点が考察として挙 げられた。

1）非疾呆患者の方が, 笑い表情形成の際の, 眼の動きが大きい.

2 ) 疾呆患者の方が，笑い表情形成の際の, 左 右差が大きい.

さらに今後, 本研究で得られた結果を, 痴呆 の早期発見などの診察技術へ, 実際に応用して いくためには, 次の3 点が, 課題として残され ている.

1）患者の臨床データとの詳細な照合

2 ) 被験者数の増加

3 ）笑い表情の質的な評価の検討

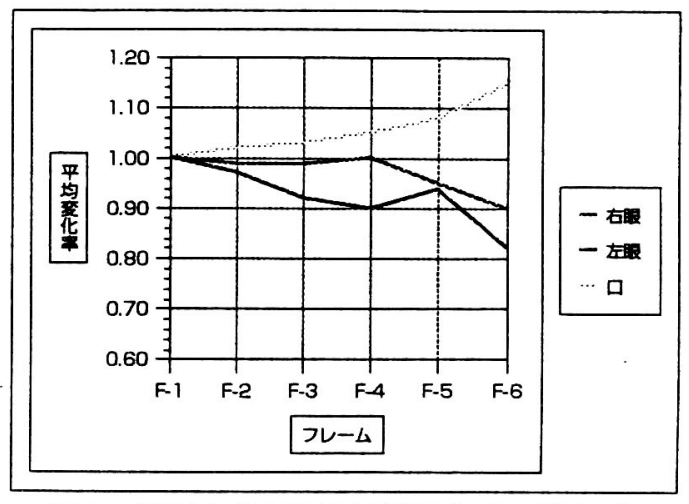

図2 疾呆患者の特徵点間距離の時系列変化

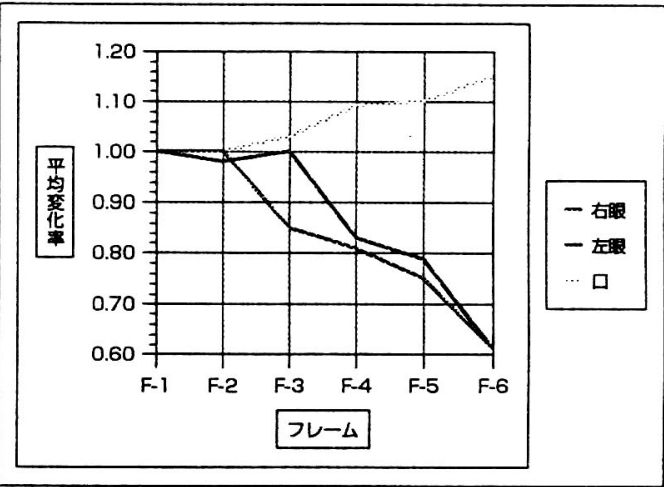

図3 非疾呆患者の特徵点間距離の時系列変化

\section{謝辞}

本研究を進めるにあたり, 早稲田大学人間科 学部卒業生の伊藤朝香さんと真野裕美子さん の，多大なるご助力を得ました。また，表情解 析用プログラムの作成については, 神奈川工科 大学情報工学科助手の井上哲理先生に, ご指導 を頂きました。ここに感謝の意を表します。

\section{参考文献}

1 ) Matsuoka S, : Various Benefits of Laughter, Special Lecture in 7th Int. Congress of Brain Electromagnetic Topography (1996)

2 ) 野呂影勇: 痴呆患者の笑い表情についての研究, ヒューマンサイエンス，8（1），pp.2-5（1995）

3 ）鳥居塚崇，野呂影勇 他：臨場感通信システムを 用いた老人の笑い表情解析, 人間工学, 30 (特別号), pp. 364-365 (1994)

4 ）津田兼六, 鈴木直人：画像解析による表情の分 析の試み(V), 日本心理学会第54回大会講演集, pp. 811 (1990) 